\title{
Sulfuric acid weathering in a High Arctic watershead
}

\author{
E.I. STEVENSON ${ }^{1 *}$, M.J. MURPHY ${ }^{2}$, K.E. RelPH ${ }^{1}$, E.T. \\ TIPPER $^{1}$, A.V. TURCHYN ${ }^{1}$, P.A.E. POGGE VON \\ STRANDMANN $^{3}$, T.R. CHRISTENSEN ${ }^{4}$ \\ ${ }^{1}$ Department of Earth Sciences, University of Cambridge, \\ CB2 3EQ, UK *eis22@cam.ac.uk \\ ${ }^{2}$ Institut for Geovidenskab og Naturforvaltning, Københavns \\ Universitet, Københavns, Denmark \\ ${ }^{3}$ Institute of Earth and Planetary Sciences, UCL and Birkbeck, \\ University of London, UK \\ ${ }^{4}$ Department of Bioscience, Aarhus University, 4000 \\ Roskilde, Denmark
}

Earth's temperature is thought to be regulated by a negative feedback between atmospheric $\mathrm{CO}_{2}$ levels and chemical weathering of silicate rocks over million-year time scales. Enhanced physical weathering in the Arctic through glacial retreat, permafrost thaw and collapse is exposing and mobilising vast amounts of finely-ground sediment to the agents of weathering. Elevated pyrite mineral oxidation caused by the exposure of sulfide minerals, such as pyrite, during physical erosion can generate sulfuric acid which can weather freshly exposed carbonate minerals and release $\mathrm{CO}_{2}$ to the atmosphere.

Here we present new coupled oxygen-sulfur isotopic data for a high Arctic River (Zackenberg River, Northeast Greenland) to partition the sources of dissolved sulfate from gypsum and pyrite end members. High frequency water chemistry data from the Zackenberg River shows how these chemical weathering reactions have evolved seasonally and annually over the past 30 years. The extent of release and sequestration of $\mathrm{CO}_{2}$ from the Zackenberg River watershed is highly dependent on the time of the season, erosional and precipitation events. The compiled datasets demonstrate that the release of $\mathrm{CO}_{2}$ from the sulfuric acid weathering of carbonate minerals is widespread. The total flux of which can, at times, outweigh that from the long-term sequestration of atmospheric $\mathrm{CO}_{2}$ via silicate weathering. This scenario could represent a possible modern-day positive climate feedback loop, which is unaccounted for in coupled $\mathrm{CO}_{2}$-climate models. 